\title{
Die stryd om die aard en omvang van die tugreg by die Nederduitse Gereformeerde Sendingkerk (1881-1994)
}

\author{
Author: \\ Mary-Anne Plaatjies Van \\ Huffel $^{1}$

\section{Affiliation:} \\ ${ }^{1}$ Department of Ecclesiology, \\ Stellenbosch University, \\ South Africa

\section{Correspondence to:} \\ Mary-Anne Plaatjies Van \\ Huffel \\ Email: \\ mapvanhuffel@sun.ac.za \\ Postal address: \\ Private Bag X1, Faculty of \\ Theology, Stellenbosch \\ University, Matieland 7602, \\ South Africa

\section{Dates:} \\ Received: 01 Dec. 2010 \\ Accepted: 27 July 2011 \\ Published: 09 Mar. 2012 \\ How to cite this article: \\ Plaatjes Van Huffel, M-A., \\ 2012, 'Die stryd om die \\ aard en omvang van die \\ tugreg by die Nederduitse \\ Gereformeerde Sendingkerk \\ (1881-1994)', HTS Teologiese \\ Studies/Theological Studies \\ 68(1), Art. \#1007, 8 pages. \\ http://dx.doi.org/10.4102/ \\ hts.v68i1.1007
}

C) 2012. The Authors. Licensee: AOSIS OpenJournals. This work is licensed under the Creative Commons Attribution License.
The struggle of the Dutch Reformed Mission Churches (1881-1994) with reference to the character and extend of discipline. In this article the struggle concerning the nature and extent of the disciplinary power in the Dutch Reformed Mission Church (DRMC) (1881-1994) is discussed. Since the establishment of the DRMC in 1881 until 1982 the Dutch Reformed Church (DRC) retained the right to censure and discipline the missionaries in the DRMC. The article argues that the struggle for disciplinary power under the Constitution of the DRMC, the Statute of the DRMC as well as under the memorandum of agreement between the DRMC and the DRC, was nothing less than an attempt by the DRMC to entrench the principles of Voetius in the disciplinary power of the church polity and church government of the DRMC. In 1982 the DRMC accepted a new church order in which these principles were entrenched. The acceptance of this church order provision concluded the DRMC's struggle for disciplinary power of all its officers, missionaries included, which already began in 1908. At the inaugural meeting of the Uniting Reformed Church in Southern Africa a Church Order was adopted in which provisions with regards to the disciplinary power based on above principles was hedged.

\section{Inleiding}

In die artikel word die stryd om die aard en omvang van die tugreg by die Nederduitse Gereformeerde Sendingkerk (NGSK) (1881-1994) beskryf. Op 14 April 1994 het die NGSK en die Nederduitse Gereformeerde Kerk Afrika (NGKA) verenig en het die Verenigende Gereformeerde Kerk in Suider-Afrika (VGKSA) tot stand gekom. Op die stigtingsvergadering was die Kerkorde met twaalf artikels goedgekeur. Die skrywer probeer in die artikel aantoon dat ' $n$ lang stryd die kerkordelike artikels en bepalinge in die Kerkorde van die VGKSA wat betrekking het op die tugreg, vooraf gegaan het. Kennis behoort geneem te word dat die Reformed Church in Afrika (RCA), en die NGKA op dieselfde wyse as die NGSK gestruktureerd was. Daar kan dus aangeneem word dat dieselfde kerkordelike reëlings wat in die NGSK die tugreg ten opsigte van sendelinge omskryf het ook van toepassing was in die NGKSA en die RCA. Die sendelinge was beskou as 'geleendes van die moederkerk'. Hierdie begrip 'geleendes van die moederkerk' wat 'in die laaste instansie' lidmate bly van die 'moederkerk' kom uit die Nederduitse Gereformeerde Kerk (NGK) se sendingreglement van 1935 en het ' $n$ groot rol gespeel in hierdie hele debat om die tugreg by die NGSK. Dit gaan dus in die stryd om die omvang van die tugreg in die NGSK aan die eenkant oor rassisme en paternalisme van die NGK en aan die anderkant oor die 'hierargiese magsuitoefening' van die NGK teenoor die sogenaamde onmondige sendingkerke. In die artikel word hoofsaaklik op laasgenoemde gekonsentreer. Die eerste sendingbeleid van die NGK was in 1935 aanvaar (Adonis 1982:78).

\section{Volgens Adonis (2003):}

Kenmerkend van hierdie beleid is dat hier van "Naturelle en Kleurlinge" gespreek word as objekte van die NGK se sending. Volgens hierdie sendingbeleid is daar geen sprake van sosiale, ekonomiese en kerklike gelykstelling tussen swart en blank nie. (p. 5)

In die artikel word ' $n$ regshistoriese ondersoek gedoen wat deskriptief en analities van aard is sowel as ' $n$ regshistoriese ondersoek na die oorsprong, die funksie en klemverskuiwings en/of die belangrikste vraagstellinge in die tugreg van die NGSK. Dit is dus ' $n$ interpretatiewe mededeling van die tugregontwikkeling by die NGSK. Die omvang en aard van die tugreg word gevolglik in die artikel regshistories geanaliseer, en daar word geargumenteer dat die meerdere vergaderings van die NGSK die bevoegdheid besit om alle ampsdraers, sendelinge ingeslote, te tug.

\section{Die ontwikkeling van die NGSK as aparte sendingkerk}

Tot aan die einde van die agtiende eeu het bekeerlinge uit inheemse bevolking of slawe en lidmate van die NGK gesamentlik dienste bygewoon en het hul gesamentlik sakramente ontvang (Kriel 1963:54). Teen 1862 het vier afsonderlike NG Kerke bestaan te wete in die Kaap, Natal, Oranje Vrystaat en Transvaal (Kleynhans 1985:347). Dié vier sinodes het gedurende 1962 verenig en het sodoende een Algemene Sinode gevorm. Die sendingwerk van die NGK in die destydse 
vier provinsies het uiteindelik tot afsonderlike kerke vir afsonderlike rassegroepe gelei.

Die NGK het op hul eerste sinode vergadering in 1824 die amp van sendeling ingestel. Die sendeling was iemand wat opleiding ontvang het om die evangelie aan die sogenaamde heidene te verkondig. 'n Reglement vir die ordening van sendelinge was in 1826 goedgekeur. Die kerkregtelike posisie en tug van sendelinge in sendingkerke was daardeur gereël. Adonis (2003:5) is van mening dat die sendingbeleid ' $n$ beleid van rasseskeiding was wat uiteindelik op die Volkskongresse van 1944 en 1947 as beleid van die Afrikaner aanvaar is. Op die sinodes van die Nederduitsche Gereformeerde Kerk van Zuid-Afrika $(1834,1837,1857)$ was die kwessie van afsonderlike bediening aan die 'heidene' bespreek (Loff 1981:22). In 1834 is 'n Ontwerp van bepalingen de Hervormde Zending Genootschappen in de Ned. Herv. Gemeenten in ZuidAfrika aanvaar wat aan die eenkant vir die stigting van 'Gemeenten der Naturellen' voorsiening gemaak het en aan die anderkant voorsiening daarvoor gemaak het dat lidmate met 'n sertifikaat van lidmaatskap by bestaande NGK-gemeentes kon aansluit (Kriel 1963:49). Kriel noem bogenoemde Ontwerp die NGK se eerste sendingbeleid (1963:48). Op sinodale vlak is dus met dié reglement ruimte geskep vir die daarstelling van afsonderlike gemeentes op grond van ras. In 1837 was genoemde Reglement hersien. Die Sendingreglement van die NGK het nie daarvoor voorsiening gemaak dat wit leraars (vervolgens genoem sendelinge) by diensaanvaarding in die NGSK, lidmate van die NGSK kon word nie en dus onder die tug en toesig van die NGSK kon val.

Op die Sinode van die Nederduitsche Gereformeerde Kerk van Zuid-Afrika 1873 is ' $n$ Binnelandse Sendingkommissie benoem wat verantwoordelik sou wees vir alle sendingwerk in die Kaapkolonie (Almanak NGK 1908:25; Kriel 1963:63). In 1876 het die Sinode van die Nederduitsche Gereformeerde Kerk van Zuid-Afrika opdrag aan die Binnelandse Sendingkommissie gegee om ondersoek in te stel na die toekoms van die sendinggemeentes. Die Binnelandse Sendingkommissie het op die Sinode van die NGK van Zuid-Afrika in 1880 'n skema voorgelê wat tien kerkregtelike aanbevelings bevat het ten opsigte van die vereniging van die verskillende sendinggemeentes tot een liggaam (Acta NGK 1880:54-57; Kriel 1956:24, 1963:67; Loff 1981:25). Op 12 November 1880 het die Sinode van die NGK tot die oprigting van 'n afsonderlike Nederduitsche Gereformeerde Zendingkerk besluit (Acta NGK 1880:57). Op Maandag 22 November 1880 was die Konstitusie vir die Nederduitsche Gereformeerde Zendingkerk van Zuid-Afrika goedgekeur (Kriel 1981:158). Die Konstitusie, bestaande uit tien artikels, was as artikel 217 tot 226 in die Wette en Bepalinge van die NGK (1881) opgeneem (Kriel 1981:158). Die grondslag is volgens Kriel (1963:67) met die aanvaarding van die Konstitusie gelê vir die rigting waarlangs 'die jong dogterkerk sou ontwikkel en uitgebou word.' Eerw. J.C. Pauw het in 'n skrywe gedateer 15 November 1880 beswaar gemaak teen die feit dat die Sendingkommissie volgens die Konstitusie vetoreg het ten opsigte van besluite wat deur die te stigte sendingkerk geneem sou word (Loff 1981:26). Pauw was volgens Chris Loff (1981:26) van mening dat die sendingkerk volgens die Gereformeerde kerkbegrip dus slegs 'n konferensie of kommissie van advies sou wees. Desnieteenstaande sy kritiek, het die stigtingsvergadering van die Nederduitsche Gereformeerde Zendingkerk van Zuid-Afrika op 05 Oktober 1881 in Wellington plaasgevind. Volgens artikel 218 moes die Nederduitsche Gereformeerde Zendingkerk van Zuid-Afrika in haar bestuur, inrigting en onderlinge toesig die bepalinge van die NGK volg in soverre dit van toepassing was op die omstandighede en behoeftes van die Nederduitsche Gereformeerde Zendingkerk van Zuid-Afrika (Acta NGK 1880:7). Die NGK se kerkreg en kerkregering word in artikel 218 as grondslag vir die Nederduitsche Gereformeerde Zendingkerk van Zuid-Afrika voorgehou. Sedert die stigting van die NGSK was daar probleme met betrekking tot die funksionering van die tugreg ten opsigte van sendelinge wat in die Nederduitsche Gereformeerde Zendingkerk van ZuidAfrika werksaam was, ondervind.

\section{Die tugreg ten opsigte van die ampsdraers van die NGSK Tugreg onder die konstitusie}

Reeds op die Sinode van die NGSK in 1891 het Teske die vraag gevra in hoeverre die kerklike wette van die NGK vir die uitoefening van die kerklike tug vir die sendinggemeente bindend was. Die voorsitter, eerw. J.C. Pauw, het geantwoord dat volgens artikel 219 van die Konstitusie die bepalinge bindend is in soverre die omstandighede en behoeftes van die NGSK toepaslik was (Acta NGSK 1891:5). Ons vind in Pauw se antwoord 'n anomalie van Gereformeerde kerkregbeginsels. Voetius, ' $n$ Nederlandse kerkregkundige, ken aan die Sinode 'n outoritatiewe bevoegdheid toe (Bouwman 1937:223). Die besluite van Sinodes bind volgens Bouwman (ibid:228) beide die gemeentes en die afsonderlike lede. Die bindende krag van die besluite was volgens Bouwman (ibid:229) deur H.H. Kuyper in De Heraut 2842 oortuigend verdedig. Hierdie bindende krag van sinodale besluite word volgens Bouwman (ibid:233) daarin begrens dat Sinodale besluite nie in stryd met die Skrif mag wees nie. Indien wel, is dit volgens artikel 31 van die kerkorde ongeldig (ibid:233). By die stigting van die NGSK het die NGK hierdie kerkregtelike beginsel geïgnoreer en was ' $n$ kerk met beperkte bevoegdhede gestig wat veral met betrekking tot die tug nie bindende besluite kon neem nie.

Teske se vraag aan die Stigtingsinode het 'n stryd rondom die aard en omvang van die tugreg ontketen wat etlike dekades sou duur. Geen voorsiening vir afsetting van ouderlinge, diakens en sendelinge was in die Konstitusie gemaak nie. Volgens Bouwman ken Voetius (Bouwman 1937:301) immers die drie dele van kerklike mag, naamlik die leer-, regeer- en die tugmag (potestas dogmatica, regiminis jurisdictionis) ook aan die Sinode toe. In die geval van die NGSK was die tugmag (potestas jurisdictionis) oor die sendelinge by die NGK gesetel. Voetius onderskei tussen verskillende grade in die tugmag, 
naamlik actus primari en actus secundarii (Bouwman 1937:301). Die actus primari verwys na waar iemand óf aan die eenkant van die nagmaal afgehou word (excommunicatio minor), óf aan die anderkant waar iemand geëkskommunikeer word (suspensio of excommunicatio maior). Die ekskommunikasie en wederopneming anders as excommunicatio minor wat deur die Kerkraad afgehandel kan word, vind in die teenwoordigheid van die gemeente plaas. Daarteenoor het die actus secundarii, volgens Voetius alleen op ampsdraers betrekking en sluit onder andere in die skorsing (suspensio), die bandlosmaking (depositio minor) uit die amp en ontsetting depositio maior uit die amp (Bouwman 1937:301). In die NGSK het hierdie besondere kerkregbeginsel nie ten opsigte van sendelinge wat in die NGSK werksaam was, gefunksioneer nie. Volgens prof. C.J. Kriel word reeds met artikel 221 en 222 van die Konstitusie van die Sendingkerk (1881) die dubbele lidmaatskap van sendelinge in die vooruitsig gestel (Skema NGSK 1978:70). Die sendelinge het direk onder die opsig en tug van die NGK resorteer (Kriel 1981:160). Die tugreg ten opsigte van sendelinge by die NGSK asook die bevoegdheid van die meerdere vergaderinge van die NGSK om uitspraak te lewer en selfs tot die uitvoering van 'n vonnis tot skorsing of afsetting oor te gaan, was deur die Konstitusie beperk en sodoende was ook die selfbeskikking van die NGSK aan bande gelê. Voetius daarteenoor is van mening dat die Sinode wel ekskommunikasiemag het (Bouwman 1937:342). Op vraag 22 of elke deel van die kerklike mag, ook ekskommunikasie, ingeval van wanbestuur en ongeneeslike verderf, aan die sinodale vergadering van die kerke toegeken kan word, het Voetius (Bouwman 1944:46) geantwoord dat hy nie kan sien waarom in bovermelde gevalle dit ontken kan word nie.

Die kwessie van tugreg ten opsigte van die sendelinge het gedurende 1908 aan die orde kom. Gedurende 1908 het die Middellandse Ring ds J.A. van Niekerk van Upington se band weens onsedelike gedrag losgemaak. Die Ring het die Sinode versoek om hul besluit te bekragtig en sy status terug te trek, aangesien algehele afsetting slegs deur die Sinode kon geskied (Acta NGSK 1908:4). Die NGSK Sinode 1908 het eenparig besluit dat J.A. van Niekerk onbevoeg is vir die leraarsamp en het sy status ontneem (Acta NGSK 1908:5). Die Sinode van die NGK in Suid Afrika (1908) het die hele aangeleentheid met betrekking tot die tug van die sendelinge na hul Regskommissie verwys ten einde die Sinode met advies te bedien (Kriel 1963:108). Onder andere moes die Regskommissie vasstel of dit binne die bevoegdheid van die NGSK lê om 'n sendeling te skors en/of af te set. Die Sinode van die NGK SA (1909) het op aanbeveling van die Regskommissie besluit dat die sendelinge onder die tug van die Ringe van die NGK wat hulle gelegitimeer het, staan (Acta NGK 1909:101). Die NGSK was dus nie bevoeg om ten opsigte van wangedrag sendelinge te skors en/of af te set nie. Die Sinode van die NGKSA (1909) het ook besluit om die hele aangeleentheid insake die uitoefening van die kerklike tug na die Binnelandse Sending-subkommissie te verwys wat by die volgende Sinode verslag moes lewer (Acta NGK 1909:92). Die NGK eien hul hierdeur meerdere gesag in die NGSK toe. Die mag van die meerdere vergadering is volgens Voetius (Bouwman 1937:193) 'n helpende mag (potestas auxiliaria) ( $\mathrm{Pol} \mathrm{Eccl} \mathrm{228).} \mathrm{In} \mathrm{die} \mathrm{kerkverband} \mathrm{is} \mathrm{alle}$ kerke en ampsdraers gelyk en verleen elkeen aan mekaar raad en hulp. Voetius (Bouwman 1937:193) wys dit egter af dat die helpende mag as 'n ekwivalent vir adviserende mag beskou kan word. Voetius (ibid:134, 194) is in Pol Eccl IV van mening dat die Sinode met haar mag korrupte kerke moet help en nie aan die verderf mag oorlaat nie. Die Sinode kan vervolgens ingryp in die partikuliere sake van 'n kerk en so dus deur die toepassing van tugmiddele weer die orde in die kerk herstel. Die mag van die meerdere vergadering is dus volgens Voetius (ibid:196) wesenlik dieselfde as dié van die mindere vergadering. Die Binnelandse Sendingkommissie daarteenoor kon ingryp in die partikuliere sake van die NGSK.

Die Sinode van die NGSK 1912 het na aanleiding van die uitspraak van die Sinode van die NGK 1909 'n mosie aanvaar (met die steun van ds D.S. Botha van die Binnelandse Sendingkommissie) dat die NGSK self die tug op die sendelinge behoort toe te pas (Botha 1981:160). Die NGSK het met dié besluit op voetspoor van Voetius beklemtoon dat die tugreg van die Kerkraad van die plaaslike gemeente, en dus nie op die Ring of Sinode of die Binnelandse Sendingsubkommissie oorgedra kon word nie. Daar kan 'n groeiende bewussyn by die NGSK onderskei word dat die helpende mag (potestas auxiliaria) by die NGSK se meerdere vergaderings tuis hoort en nie aan 'n subkommissie van die NGK nie. Die Sinode van die NGK 1915 het egter besluit dat hierdie reg alleen die NGK toekom (Kriel 1981:160).

\section{Tugreg onder die Grondwet}

Die tydperk 1916 tot 1956 kenmerk volgens Kriel (1981:160) 'n tydperk van beperkte outonomie in die NGSK. Op die Sinode van die NGK 1915 is die Konstitusie van 1880 herroep en is 'n konsep grondwet vir die NGSK goedgekeur (NGK Wetboek 1915 art. 254-66). Die konsep grondwet is in die NGK Wetboek 1915 opgeneem. Die Grondwet het aan die eenkant die Gereformeerde kerkregtelike beginsel erken dat die tug en regering in die NGSK deur die kerkrade, Ringe, algemene vergadering of Sinode (art. 3) uitgeoefen word, maar het aan die anderkant in artikel 6 bepaal dat die sendelinge direk onder die opsig en tug van die NGK val (Kerkwet NGSK 1917). Die afsetting van sendelinge deur die Binnelandse Sending-subkommissie kon volgens artikel 6 alleenlik ooreenkomstig die kerkregtelike bepaling van die NGK geskied en kon dus sonder die medewerking van die NGSK plaasvind. Volgens Voetius (Bouwman 1937:312) kan die meerdere vergadering by oortreding van kerkordelike bepalinge en ongehoorsaamheid aan sinodale besluite, asook in gevalle van wanbestuur en onmag, van die tugreg gebruik maak en is die meerdere vergadering verder ook bevoeg om in die plaaslike kerk haar tugmag uit te oefen. Voetius ken volgens Bouwman (1937:325) aan die Sinodes die reg toe om haar besluite insake tug in die plaaslike kerk tot uitvoering te bring, sonder dat die Kerkraad tot die handeling instem (ibid:325-326). Die Sinode kan, volgens Bouwman (ibid:327), 
buite die plaaslike Kerkraad die vonnis voltrek. Hierdie mag het die NGK haar in die NGSK toegeëien.

Tot en met 1932 was slegs wit leraars in die NGSK werksaam. Eers gedurende 1932 was die eerste 'gekleurde' persone as leraars in die NGSK gelegitimeer en gedurende 1935 was die eerste 'gekleurde' persone as predikante in die NGSK georden te wete P. Solomon en A.D. Andries. Op die NGSK Sinode in 1932 het 'n ouderling van Caledon, C.F.D. Viljoen, en die ouderling van Immanuel, J.N. Kearns, gevra:

of die leraar van die Sendingkerk lid van die NGSK is; en of daar 'n kleurstreep is tussen die moeder- en Sendingkerke, of God 'n aannemer van die persoon is en of ' $n$ lid van die Sendingkerk lid van die 'moederkerk' kon word. (Acta NGSK 1932:14)

Die NGSK Sinode het bevestig dat 'n sendeling lid van die NGSK is kragtens die 'feit dat die Sendingkerk as geheel aan die Moederkerk behoort' en dat hy na sy bevestiging deur die voorsitter van die Ring as lid van die Ring van die NGSK verklaar is' (Acta NGSK 1932:46). Sendelinge het hul lidmaatskap by die NGK behou en het volgens Kriel (1963:110) kragtens hul lidmaatskap en amp onder die jurisdiksie van die NGK se Ringe geval. Aangesien die wetsbepalinge van die NGSK tot en met 1932 slegs voorsiening gemaak het vir tugmaatreëls teen kerkraadslede van genoemde Sendingkerk, is daar in die Kerkwet 1937 in lyn met artikel 239 (13) van die NGK voorsiening vir die bestraffingsmaatreëls vir die sogenaamde 'Kleurlingleraar' gemaak (Acta NGSK 1937:16-17, 25-27, 174).

Op die NGSK Sinode in 1937 was wetswysigings goedgekeur dat die Sinode die reg het om ingeval van 'Kleurlingleraars' die Akte van Toelating op kennisgewing van die Ring in te trek (Acta NGSK 1937:37). Sedert 1937 is in die NGSK 'n onderskeid in die Kerkwet met betrekking tot die toepassing van die tugreg tussen sendelinge en 'Kleurlingleraar' gemaak (Kerkwet NGSK, art. 153(A) 1950:59). Dit het tot groot spanning in die NGSK gelei. Die NGSK kon slegs die tugreg oor die ouderlinge en diakens asook leraars vanuit die NGSK uitoefen. Die opheffing van die sensuur van 'n geskorste 'Kleurlingleraar' of evangelis sou deur die liggaam wat hom geskors het, geskied. Die herstel van 'n geskorste 'Kleurlingleraar' kon slegs deur die Sinode op aanbeveling van die Ring wat hom geskors het, geskied. Die Binnelandse Sending-subkommissie, daarenteen, kon sonder die inspraak van die NGSK, sendelinge tug. Die NGK het daardeur op 'n paternalistiese wyse die bestuursmag oor die NGSK uitgeoefen en het 'n sekere mate van kerklike outoriteit en sinodale bevoegdheid oor die NGSK behou. Voetius daarteenoor is volgens Van Lonkhuyzen (1924:10) van mening dat die mag van die meerdere vergadering teenoor die plaaslike kerk nie 'privatief' is nie, dit wil sê, dit beroof nie die plaaslike gemeente van haar mag en outoriteit nie. Volgens artikel 334 in die NGK se kerkorde het die Ringe toesig gehou oor die gemeentes binne die ressort; die algemene belange van die gemeente behartig; oor die nakoming van die kerklike wette en bepalings gewaak; en kerklike tug oor die ampsdraers uitgeoefen, met die voorbehoud, dat die sendelinge hul sou onderwerp aan die tug van die NGK ooreenkomstig die wette van die NGK se eie bepalinge en wette (Wette en bepalinge NGK 1953:91). Die sendelinge moes hul daarvolgens aan die sinodale gesag van die NGK onderwerp (Wette en bepalinge NGK 1953:91). Die Binnelandse Sending-subkommissie en/of NGK het die bevoegdheid gehad om inisiatief te neem met betrekking tot die kerklike sensuur, afsetting en implementering van tugtoepassing met betrekking tot sendelinge. Die NGK het deur middel van die Grondwet aan hul sinodale kommissie dwingende regsmag toegeken om daadwerklike tuguitoefening ten opsigte van die sendelinge toe te pas. Hierdie bevoegdheid kom volgens Voetius (Bouwman 1937:353) beide die plaaslike gemeente en die meerdere vergadering toe. Voetius (Bouwman 1937:353) sê nêrens in vraag 23 dat die gemeente alleen die regeermag het om verdorwe kerkrade af te set nie. In werklikheid erken Voetius in vraag 23 dat die gemeente uit eie hoofde die ampbevoegdheid van die ampsdraers kan wegneem, indien die helpende macht van die kerkverband ontbreek (Bouwman 1937:354,1944:49). Voetius ontken volgens Bouwman(1944:50) in vraag 23 volstrek dat Sinodes en classis die eensydige reg het om in die sake van 'n partikuliere kerk wat tot dwaalleer of skisma verval het in te gryp, te ekskommunikeer, af te set en/of die oordeel in die plaaslike kerk te voltrek. Bouwman (1937:370) is van mening dat Voetius hom in Pol Eccl IV.121, sub 9 rig teen hiërargie wat ook in artikel 84 van die Dordtse Kerkorde (DKO) bestry word. Artikel 84 van die DKO beklemtoon die gelykwaardigheid van die ampsdraers en die kerke onderling en handhaaf die selfstandigheid van die partikuliere kerk teenoor elke ander partikuliere kerk binne kerkverband (Bouwman 1937:371). Ter handhawing van die selfstandigheid van die gemeente beroep Voetius hom telkens op artikel 30 van die DKO waarvolgens die Sinode nie op sy eie, kerklike sake mag afhandel nie (Bouwman 1937:371). Die NGSK het nie die bevoegdheid gehad om tugsake van sendelinge af te handel nie. Die NGSK moes die Algemene Sendingkommissie van die NGK in kennis stel indien sendelinge die NGSK sonder opgaaf van redes verlaat het (Wette en bepalinge NGK 1953:91 art. 337). Die NGSK was volgens die Grondwet nie geregtig op die voltrekking van die tugreg op sendelinge nie (Wette en bepalinge NGK 1953: 94 , art. 327).

Voetius (Bouwman 1937:301) onderskei tussen verskillende grade in die tugmag, naamlik Actus primari en actus secundarii. Die Actus primari verwys na waar iemand of aan die eenkant van die nagmaal afgehou word (excommunicatio minor), of aan die anderkant waar iemand geëkskommunikeer word (suspensio of excommunicatio maior). Die ekskommunikasie en wederopneming anders as excommunicatio minor wat deur die Kerkraad afgehandel kan word, vind in die teenwoordigheid van die gemeente plaas. Daarteenoor het die actus secundarii, alleen volgens Voetius in Pol Eccl IV , 868-869 op ampsdraers betrekking en sluit onder andere in die skorsing (suspensio), die bandlosmaking (depositio minor) uit die amp en ontsetting depositio maior uit die amp in (Bouwman 1937:301). Die beginsels van Voetius kan duidelik onderskei word in artikel 279.3 van die NGK. Die Ringe van die NGK kon van die volgende bestraffingsmiddels gebruik maak: 
- Bestraffing, na die eis ingerig is, deur die voorsitter, namens die Ring, óf in, óf buite die vergadering.

- Skorsing in die diens vir 'n bepaalde tyd met of sonder die gebruik van die Bondseëls.Skorsing in die diens vir 'n onbepaalde tyd met of sonder die gebruik van die Bondseëls.

- Gehele intrekking van die Akte van toelating tot die predikdiens en die bediening van die Bondseëls (Wette en bepalinge NGK 1953:art. 279.3).

Volgens artikel 324 (Wette en bepalinge NGK 1953:87) kon 'n sendeling wat sy status as sendeling verbeur het, by die Sinode van die NGK of by die sinodale kommissie van die NGK aansoek doen vir herstel van status. Die Sinode of die Sinodale Kommissie van die NGK het toestemming verleen dat die applikant by die Eindeksamenkommissie vir Sendingkandidate vir colloquium doctum kon aanmeld. Die NGK het met betrekking tot die afsetting en sensuur van sendelinge mag uitgeoefen wat uiteraard by die meerdere vergaderings van die NGSK tuis gehoort het. Die NGK se beleid met betrekking tot sendelinge was paternalisties en hiërargies. Die NGK het as 'n soort senatus ecclesiasticus (as 'n opperkerkraad) gefungeer wat tot skorsing en self uitsetting van die sendelinge kon oorgaan. Die Sinode van die NGSK kon wel aanbevelings met betrekking tot die bandlosmaking van 'n sendeling doen, maar die daadwerklike uitoefening van die besluit het nie op voetspoor van die DKO by die Ring of Kerkraad berus nie, maar by die NGK. Die Kerkraad van die NGSK het nie potestas autorisativa of die mag om met gesag op te tree en sensuur op sendelinge toe te pas, beskik nie. Aan die Binnelandse Sending-subkommissie was volledige leer-, regeer- en tugmag wat volgens die Gereformeerde kerkreg uiteindelik by die Kerkraad tuis hoort, toegeken.

\section{Tugreg onder die Akte van ooreenkoms}

Die Sinode van die NGSK 1954 het besluit dat die Grondwet drasties hersien moes word. Op die Sinode van die NGSK 1966 was die kerkregtelike posisie van die sendelinge in die lig van die Gereformeerde kerkreg en die Sendingwetenskap beoordeel (Skema NGSK 1966:354-362; Botha 1981:162). Die kommissie wat hieroor verslag gedoen het, het geoordeel dat kerkregtelik gesien daar geen rede hoegenaamd bestaan waarom die NGSK in enige opsig grondwetlik aan die NGK ondergeskik gestel moes wees nie (Skema NGSK 1966:355). Die kommissie het verder geoordeel dat die enigste moontlike verklaring vir die ondergeskiktheid in die sosio-ekonomiese posisie van die 'Kleurlingbevolking ten opsigte van die Blankes' gesoek behoort te word. Ironies genoeg maak die verslag nie melding van paternalisme of rassisme nie. Die amp word volgens die Kommissie beoefen in die boesem van die plaaslike gemeente wat volledig en volkome kerk is en dus oor al die ampte beskik kragtens sy eie outonomie (Skema NGSK 1966:355). Die kommissie maak dit duidelik dat daar geen statusverskil tussen 'n predikant van 'n tuisgemeente en 'n missionaire predikant is nie en dat geen predikant aan meer as een kerk verbonde kan wees nie. Die kommissie het geoordeel dat die sendeling behoort lidmaat van die gemeente wat hy bedien te wees (Skema NGSK 1966:358).
Die NGSK Sinode 1966 het besluit om die kwessie van lidmaatskap van sendelinge by die Federale Raad aanhangig te maak (Botha 1981:162).

Die Grondwet (1975) het onder andere in artikel 9.3 bepaal dat alle ongesensureerde lidmate van die NGSK die reg het om besware of klagtes teen ' $n$ wit leraar by die bevoegde kerkvergadering van die NGSK in te dien. Die betrokke kerkvergadering van die NGSK ondersoek die klagtes of beswaar en as dit gegrond blyk te wees, word die klagte tesame met die besluit van die bevoegde kerkvergadering van die NGSK aan die voorlopige kerkvergadering van die Gefedereerde Nederduitsche Gereformeerde Kerke voorgelê. Artikel 9.4 van die Grondwet het verder bepaal dat die NGSK die actuarius van die NGK in kennis stel as 'n wit leraar sy bediening sonder opgaaf van redes neerlê (Skema NGSK 1978:70-71). Op die Sinode van die NGSK 1970 is ' $n$ memorandum oor die beoordeling van die posisie van die sendelinge in die NGSK bespreek (Acta NGSK 1978:115-122). Wetswysigings met betrekking tot die posisie van sendelinge was op die Sinode goedgekeur. Sedert 1970 het die NGSK se Kerkwet (1970:12) bepaal dat 'n wit leraar wat ' $n$ beroep na 'n ander werkkring aanneem van sy betrekking tot die gemeente deur die betrokke NGSK Kerkraad op 'n wettig gekonstitueerde vergadering ontslaan behoort te word. 'n Akte van demissie, onderteken deur die Kerkraad van die plaaslike NGSK-gemeente moet aan sodanige leraar oorhandig word. Met betrekking tot die kerkregtelike posisie van sendelinge in die NGSK is die volgende beskrywingspunte op die Sinode van die NGSK (1974) ingedien:

- 'Blanke leraars ook voorwerp van tug: stappe te doen om blanke leraars in die NG Sendingkerk in Suid-Afrika onderhewig aan die kerklike opsig en tug van die NG Sendingkerk te maak terwyl en solank hulle leraars in hierdie kerk is' (Acta NGSK 1974:262).

- 'Volledige lidmaatskapswording van blanke leraars in die NG sendingkerk: Die Hoogeerwaarde Sinode aanvaar die beginsel dat alle diensdoende leraars in die NG Sendingkerk lidmaat word van die NG Sendingkerk met inbegrip van volledige kerklike opsig en tug, insluitende die reg tot ontneming van status' (Skema NGSK 1974:268-269).

Met betrekking tot die kerklidmaatskap van die sendelinge besluit die NGSK Sinode 1974 onder andere dat "n Leraar se ampsbediening vloei voort uit sy lidmaatskap en nie omgekeerd nie. Deur die bevestiging as leraar word sy lidmaatskap oorgedra na die gemeente wat hy bedien' (Acta NGSK 1974:451). Die NGSK Sinode 1974 het dubbele lidmaatskap en die beskerming van die ampsbediening van die sendeling deur die NGK afgewys (Acta NGSK 1974:452). Die Sinode het besluit om artikel 26 van die Algemene Sendingreglement te handhaaf met betrekking tot die tugtoepassing en uiteindelike afsetting van die sendelinge (Acta NGSK 1974:452). Met betrekking tot dubbele lidmaatskap word die Permanente Regskommissie opdrag gegee om gedurende die reses 'n deeglike studie te maak van die beginsel van dubbele lidmaatskap in die lig van die 
begrippe 'kerk' en 'kerkverband' (Acta NGSK 1974:363). Prof. C.J. Kriel, lid van die Permanente Regskommissie, het ' $n$ studiestuk opgestel (Skema NGSK 1978:77). In sy 'Studiestuk oor dubbele lidmaatskap' is hy van mening dat dit regstegnies nie moontlik is om ' $n$ lid van 'n Kerkraad, Ring, Sinode te wees met volle regte, voorregte en stemreg sonder om 'n lidmaat van genoemde kerk te wees nie (Skema NGSK 1978:77). Kriel (Skema NGSK 1978:70-77) dui aan dat beide dubbele lidmaatskap en tuguitoefening van die NGK oor wit leraars van die NGSK geen Gereformeerde kerkregtelike gronde het nie.

Op 27 November 1975 het 'n Akte van Ooreenkoms tussen die Streeksinode Wes-Suid-Kaap van die NGK en die NGSK tot stand gekom om die verhouding tussen die twee kerke kontraktueel te reël (Acta NGSK 1978:16; Skema NGSK 1986:587). Daarmee het die Grondwet verval en is 'n nuwe era in die NGSK betree. Tot en met die opheffing van die Grondwet het wit leraars 'n vorm van dubbele lidmaatskap geniet en het die NGK tugreg oor sodanige leraars in die NGSK uitgeoefen. Die Akte van Ooreenkoms met die Kaapse Sinode van die NGK was nie vir die ander Streeksinodes van die NGK bindend nie en moes gevolglik vervang word deur 'n ooreenkoms met die Algemene Sinode van die NGK. Die Akte van Ooreenkoms was gevolglik eers op die daaropvolgende Sinode van die NGSK (1978) goedgekeur. In die Akte van Ooreenkoms word onder andere die kerkregtelike posisie van wit leraars in diens van die NGSK gereglementeer (Skema NGSK 1978:72). Die Akte het bepaal dat die beroeping, bevestiging en legitimering van 'n gelegitimeerde uit die NGK volgens die bepalinge en reglemente van die NGSK moes geskied. Die NGSK het onder andere die opleiding en legitimasie van bedienaars van die Woord deur die NGK vir die doel van diens in die NGSK erken, naamlik:

- leraars en proponente in die NGK is beroepbaar in die NGSK

- gelegitimeerdes uit die NGK wat diens in die NGSK aanvaar het, bly beroepbaar in die NGK

- die beroeping, bevestiging en demittering van 'n gelegitimeerde uit die NGK geskied volgens die bepalinge en reglemente van die NGSK

- die bedieninge word uitgeoefen ooreenkomstig die bepalinge en reglemente van die NGSK

- deur sy bevestiging in 'n gemeente van die NGSK word hy ook lidmaat van die NGSK

- nadat sy dienste in die NGSK beëindig is, is hy slegs lidmaat van die NGK waar hy hom vestig

- hy staan ten opsigte van die opsig en tug onder sowel die NGK en die NGSK

- in die tugtoepassing word gehandel ooreenkomstig die bepalinge en reglemente van die NGSK

- wanneer die bestraffing neerkom op losmaking van die band tussen hom en die gemeente, word sy lidmaatskap in die NGSK beëindig

- word alle stukke wat betrekking het op die saak vir behandeling aan die NGK deurgestuur en val hy onder die jurisdiksie van die betrokke Ring waar sy arbeidsveld was
- wanneer die bestraffing neerkom op 'n beslissing dat sy Akte van Toelating ingetrek behoort te word, gee die Ring wat dit opgelê het, en in die geval van hoër beroep die Sinode van die NGSK, daarvan kennis aan die NGK met voorlegging van alle stukke wat op sy saak betrekking het

- en sy Akte van Toelating kan slegs deur die NGK ingetrek word (Skema NGSK 1978:33-34).

'n Tweeslagtigheid met betrekking van die tug van wit leraars word in die Akte van Ooreenkoms onderskei. Alhoewel hul onder die opsig en tug van die NGSK val, het die NGK die reg tot die finale toepassing van die tug voorbehou. Die NGK se tugreg ten opsigte van die sendelinge, naamlik dat 'n meerdere vergaderinge van ' $n$ ander kerk oor volle leer-, regeer- en tugmag in die NGSK beskik, was op die NGSKSinode 1978 as onhoudbaar afgewys. In artikel 84.2 van die Kerkorde van die NGSK 1978 word dit duidelik gestel dat die NGSK tugreg het oor alle ampsdraers, sendelinge ingeslote, wat in diens van die NGSK staan. Hiervolgens is die meerdere vergaderinge van die NGSK bevoeg om tugmag teenoor alle bedienaars van die Woord en die kerkraadslede van die NGSK uit te oefen. Die NGSK beklemtoon hiermee op voetspoor van Voetius (Bouwman 1937:353) dat 'n meerdere vergadering of 'n kommissie van 'n ander kerk nie oor die reg beskik om self tugtoepassing in 'n plaaslike gemeente te voltrek nie. Voetius (Bouwman 1937:353) ontken immers in vraag 23 volstrek dat Sinodes en classis die reg het om in die sake van 'n partikuliere kerk wat tot dwaalleer of skisma verval het, in te gryp, te ekskommunikeer, af te set en/of die oordeel in die plaaslike kerk te voltrek (Bouwman 1944:50). Bouwman (1937:370) is van mening dat Voetius hom onder andere in Pol Eccl IV ,121, sub 9 rig teen hiërargie wat ook in artikel 84 van die DKO bestry word. Artikel 84 van die DKO beklemtoon die gelykwaardigheid van die ampsdraers en die kerke onderling en handhaaf die selfstandigheid van die partikuliere kerk teenoor elke ander partikuliere kerk binne kerkverband (Bouwman 1937:371). Ter handhawing van die selfstandigheid van die gemeente beroep Voetius hom telkens op artikel 30 van die DKO waarvolgens die Sinode nie op sy eie, kerklike sake mag afhandel nie (Bouwman 1937:371). Die NGSK gaan van die veronderstelling uit dat geen ampsdraers van die NGSK buite die deur die bevoeg verklaarde strukture van die NGSK afgeset mag word nie.

Die Algemene Sinodale Kommissie (ASK) van die NGSK het op 15 tot 16 Augustus 1984 die Permanente Regskommissie versoek om 'n memorandum aan die Skakelkommissie van die NGK voor te lê insake die opsegging van die Akte van Ooreenkoms (Skema NGSK 1986:90). Die NGSK wou die Akte van Ooreenkoms met ' $n$ kerkorde vervang. Op die NGSK Sinode 1982 was die Kerkorde van die NGSK goedgekeur. Die Kerkorde van die NGSK 1982 het onder andere die prosedure waarvolgens die tug teenoor alle diensdoende predikante, sendelinge ingeslote, van die NGSK uiteengesit (Kerkorde van die Nederduitse Gereformeerde Sendingkerk 1982:10 art. 13). Met die aanvaarding van die kerkordelike bepalinge was die NGSK se stryd om die tug oor al haar ampsdraers, sendelinge ingeslote, wat reeds 1908 begin het, uit te oefen, afgesluit. Sodoende het die NGSK daarin geslaag om die 
beginsels van Voetius met betrekking tot die tugreg in hul kerkreg en kerkregering te verskans te kry.

\section{Die tugreg ten opsigte van die ampsdraers van die VGKSA}

Op die Stigtingsinode van die VGKSA was die vooraf ooreengekome konsep Kerkorde bestaande uit 12 artikels goedgekeur (Acta VGKSA Algemene Sinode 1994:360-365). Die kerkordelike bepalings met betrekking tot die tugreg word in die kerkorde van die VGKSA verskans. Artikel 9.4 van die Kerkorde van die Algemene Sinode van die VGKSA dui aan dat die Ring tugsake met betrekking tot bedienaars van die Woord en diegene wat in ' $n$ verkose amp staan in behandeling neem. Bepaling 120.1 bepaal ten opsigte van 'n bedienaar van die Woord dat' $n$ tugmaatreël van skorsing deur die Ring, ná ' $n$ deeglike ondersoek en genoegsame blyke van skuld geneem kan word (Kerkorde Streeksinode Kaapland 1994:art. 120.1). Die kerkorde bepaal verder ook in artikel 123 dat bedienaars van die Woord wat met behoud van status in 'n ander amp staan, teologiese dosente, proponente en emeriti, onderworpe is aan die vermaning en tug van die Ring binne wie se ressort hulle woon en van die Kerkraad van die gemeente waaraan hulle behoort. Die kerkorde dui ook aan dat ondersoek en uitspraak in die geval van die indiening van 'n klagte of kennisgewing van gerug deur die Ring behoort te geskied (bep. 124.1). Bestraffingmaatreëls waarvan gebruik gemaak kan word sluit onder andere in: bestraffing en vermaning, na eis ingerig, in of buite die vergadering, skorsing in diens vir 'n bepaalde of onbepaalde tyd, ontslag uit die gemeente met verval van alle regte op vrye woning en ander emolumente. In die geval van leraars, proponente en evangeliste geskied afsetting deur die Streeksinode op aanbeveling van die Ring (bep. 126.1). Volgens artikel 10.2 het die Streeksinode besluitnemingsbevoegdheid oor tughandelinge en hoër beroepe. Bepaling 120.2 bepaal verder dat 'n maatreël van afsetting slegs deur die Streeksinode geneem kan word op voordrag en aanbeveling van die Ring. 'n Hoërberoep teen 'n tugmaatreël wat 'n aanbeveling tot afsetting bevat, kan deur geen ander liggaam as die Streeksinode behandel word nie:

Daartoe voeg die beswaarde(s) hulle skriftelik by die voorsitter van die Ring wat die besware wat ontvang is terstond in die hande van die Ringskommissie te stel om daaromtrent ondersoek in te stel. (Bep. 125.2)

As iemand, hetsy 'n klaer of 'n beklaagde, of ' $n$ beswaarde in 'n leergeskil, beswaard is vanweë ' $n$ besluit of beslissing van 'n Ring, en hy/sy hom/haar op die Sinode of die Sinodale Kommissie beroep, moet hy/sy binne twee maande ná sodanige uitspraak daarvan kennis gee aan die voorsitter van die Ring en 'n afskrif van die uitspraak aanvra, indien hy/sy dit nog nie ontvang het nie (bep. 134). 'n Leraar of proponent wat afgesit is, kan slegs weer beroepbaar gestel word nadat hy/sy deur die Sinode in die amp herstel is. Die herstel van 'n afgesette leraar of proponent geskied deur die Streeksinode op aanbeveling van die Ring wat hom/ haar geskors het (bep. 137.2.2). In artikel 11.9 word aangedui dat die besluitnemingsbevoegdheid in tugsake rakende die leer van die Kerk wat in hoër beroep aanhangig gemaak is by die Algemene Sinode tuis hoort (Kerkorde Algemene Sinode VGKSA 2006:art. 11.9). Wanneer leertug toegepas is vanweë 'n dwaling in een of meer fundamentele leerstukke soos in die belydenisskrifte geformuleer, gee die skriba van die gebiedsinode onverwyld hiervan kennis aan die belanghebbende partye. Uitspraak word op die Algemene Sinode gegee met 'n twee-derde meerderheid van die aanwesige lede na aanleiding van die stukke, voordrag en aanbevelings van die Tydelike Regskommissie of Algemene Regskommissie. 'n Wettige opgelegde tugmaatreël van skorsing kan nie opgehef word voordat genoegsame blyke van grondige boetvaardigheid en berou gegee is en versoening tot stand gekom het nie. Die bevoegdheid om die skorsing op te hef berus by die vergadering wat die tugmaatreël geneem het of wat in appèl uitspraak gegee het. 'n Bedienaar van die Woord wat afgesit is weens leertug en wie se appèl deur die Algemene Sinode van die hand gewys is, kan slegs weer beroepbaar gestel word nadat hy/sy deur die Algemene Sinode in sy/haar amp herstel is. Uit bovermelde kerkorde bepalings van die VGKSA kan spore van Voetius se stellingname met betrekking tot die actus secundarii naamlik skorsing (suspensio), bandlosmaking (depositio minor) uit die amp en ontsetting uit die amp (depositio maior) onderskei word.

\section{Gevolgtrekking}

Die artikel probeer aantoon dat die huidige kerkordelike artikels en bepalinge in die VGKSA se kerkorde vormgewing gevind het na 'n lang stryd oor die aard en omvang van die tugreg. Die artikel dui aan dat die stryd alreeds sedert 1908 gevoer was en dat dit uiteindelik met die aanvaarding van die kerkordelike bepalinge op die Sinode van die NGSK (1982) afgesluit is. Sodoende het die NGSK daarin geslaag om Voetius se beginsels met betrekking tot die tugreg in hul kerkreg en kerkregering te verskans.

\section{Erkennings \\ Mededingende belange}

Die outeur verklaar dat sy geen finansiële of persoonlike verbintenis het met enige party wat haar nadelig kon beïnvloed in die skryf van hierdie artikel.

\section{Literatuurverwysings}

Acta van die Nederduitsche Gereformeerde Kerk van Zuid-Afrika, 1834, I. Hofmeyer's Chambers, Kaapstad.

Acta van die Nederduitsche Gereformeerde Kerk van Zuid-Afrika, 1837, I. Hofmeyer's Chambers, Kaapstad.

Acta van die Nederduitsche Gereformeerde Kerk van Zuid-Afrika, 1857, I. Hofmeyer's Chambers, Kaapstad.

Acta van die Nederduitse Gereformeerde Kerk, 1880, I. Hofmeyer's Chambers, Kaapstad.

Acta van die Nederduitse Gereformeerde Kerk, 1909, Van de Sandt \& de Villiers Drukpers, Kaapstad.

Acta van die Nederduitse Gereformeerde Sendingkerk, 1891, Townshend en Zoon Drukkers, Kaapstad.

Acta van die Nederduitse Gereformeerde Sendingkerk, 1908, Townshend en Zoon Drukkers, Kaapstad.

Acta van die Nederduitse Gereformeerde Sendingkerk, 1916, Paarldrukpers, Paarl.

Acta van die Nederduitse Gereformeerde Sendingkerk, 1932, Paarldrukpers, Paarl. 
Acta van die Nederduitse Gereformeerde Sendingkerk, 1937, Paarldrukpers, Paarl. Acta van die Nederduitse Gereformeerde Sendingkerk, 1974, Paarldrukpers, Paarl. Acta van die Nederduitse Gereformeerde Sendingkerk, 1978, Paarldrukpers, Paarl. Acta VGKSA Algemene Sinode 1994, Paarldrukpers, Paarl.

Adonis, J.C., 1982, Die afgebreekte skeidsmuur weer opgebou, Editions Rodopi, Amsterdam.

Adonis, J.C., 2003, 'Sending en ekumene in die familie van die Nederduitse Kerk' besigtig 15 Junie 2010, by http://sun025.sun.ac.za/portal/page/portal/Arts/ Departemente1/geskiedenis/docs/adonis_hannes.pdf

Almanak voor de Nederduitsch Gereformeerde Kerk in Zuid-Afrika voor het jaar 1908: $59^{\text {ste }}$ jaargang, Van de Sandt \& de Villiers Drukpers, Kaapstad.Bepalinge en reglemente van die Nederduitse Gereformeerde Sendingkerk, 1970, Paarldrukpers, Paarl.

Botha, D.P., 1981, 'Kerkregtelike selfverwesenliking', in C.J. Kriel (red.) 1981, Die eerste eeu: Die Ned Geref Kerk in Suid-Afrika, 5 Oktober 1881 - 5 Oktober 1981, pp. 158-154, Paarldrukpers, Paarl.

Bouwman, M., 1937, Voetius over het gezag der synoden, S.J.P. Bakker, Amsterdam.

Bouwman, M., 1944, Tweërlei kerkrecht? Het zoogenaamde oude kerkrecht noch oud, noch gereformeer, S.J.P. Bakker, Amsterdam.

Kerkorde Algemene Sinode VGKSA, 2006, Paarldrukpers, Paarl.

Kerkorde Nederduitse Gereformeerde Sendingkerk, 1974, Paarldrukpers, Paarl.

Kerkorde Nederduitse Gereformeerde Sendingkerk, 1978, Paarldrukpers, Paarl.

Kerkorde Nederduitse Gereformeerde Sendingkerk, 1982, Paarldrukpers, Paarl.

Kerkorde Streeksinode Kaapland Verenigende Gereformeerde Kerk in Suider Afrika, 1994, Paarldrukpers, Paarl.

Kerkwet Nederduitse Gereformeerde Sendingkerk, 1917, Paarldrukpers, Paarl.
Kerkwet Nederduitse Gereformeerde Sendingkerk, 1950, Paarldrukpers, Paarl. Kerkwet Nederduitse Gereformeerde Sendingkerk, 1970, Paarldrukpers, Paarl. Kleynhans, E.P.J., 1985, Gereformeerde kerkreg, deel I, II en III, NGK Boekhandel, Pretoria.

Kriel, C.J., 1956, Gedenkskrif NGSK. Paarldrukpers, Paarl.

Kriel, C.J., 1963, Die geskiedenis van die Ned Gereformeerde Sendingkerk in Suid-Afrika 1881-1956, 'n Historiese studie van die sendingwerk onder die Kleurlingbevolking $1881-1956$, 'n Historiese studie van
van Kaapland, Paarldrukpers, Paarl.

Kriel, C.J., 1978, Seuns in Sy wingerd, Paarldrukpers, Paarl.

Kriel, C.J., 1981, Die eerste eeu: Die Ned Geref Kerk in Suid-Afrika, 5 Oktober 1881 - 5 Oktober 1981, Paarldrukpers, Paarl.

Loff, C.J.A., 1981, Dogter of verstoteling? Kantaantekeninge by die geskiedenis van die Ned Geref Sendingkerk in Suid-Afrika, Paarldrukpers, Paarl.

Nederduitse Gereformeerde Kerk Wetboek, 1915, Van de Sandt \& de Villiers Drukpers, Kaapstad.

Skema van die Nederduitse Gereformeerde Sendingkerk, 1937, Paarldrukpers, Paarl. Skema van die Nederduitse Gereformeerde Sendingkerk, 1966, Paarldrukpers, Paarl. Skema van die Nederduitse Gereformeerde Sendingkerk, 1974, Paarldrukpers, Paarl. Skema van die Nederduitse Gereformeerde Sendingkerk, 1978, Paarldrukpers, Paarl. Skema van die Nederduitse Gereformeerde Sendingkerk, 1982, Paarldrukpers, Paarl. Skema van die Nederduitse Gereformeerde Sendingkerk, 1986, Paarldrukpers, Paarl. Van Lonkhuyzen, J., 1924, Verzoek der eerste Christian Gereformeerde Gemeente van Chicago om het uitspraak der synode, TU, Chicago, IL.

Wette en bepalinge van die Nederduitse Gereformeerde Kerk, 1953, Nasionale drukpers, Kaapstad. 